ISA

Arboriculture \& Urban Forestry 2018. 44(1):23-38

\title{
Early Vegetation Responses to Eight Right-of- Way Integrated Vegetation Management Techniques in Northern Canada
}

\author{
Krystal M. Isbister, Eric G. Lamb, Katherine J. Stewart
}

\begin{abstract}
Integrated vegetation management programs have successfully reduced the frequency and intensity of power line rightof-way management by promoting low-growing plant communities resistant to tree invasion. To examine whether these principles are transferable to northern ecosystems, researchers tested eight treatments at four sites in Yukon, Canada. Two herbicides, imazapyr and triclopyr, were applied by three methods, as well as a native grass seeding treatment and a mowing control. Vegetation cover was recorded prior to treatment and after one year along with herbicide damage assessments. Overall, treatments caused significant changes to vascular plant communities after one year. Short-term control of woody target species was greater in chemically-treated plots $(66 \%-94 \%)$ than with mechanical methods $(<55 \%)$. All treatments caused a minor reduction in non-target vegetation cover. In seeded plots, seedlings emerged but total non-target species cover was reduced by seedbed preparation. Triclopyr broadcast spray reduced non-target vegetation cover by $<10 \%$, but the common shrub, kinnickinnick (Arctostaphylos uva-ursi), was highly impacted. Selective application of triclopyr effectively controlled targets with minimal effects on non-target species. Imazapyr consistently caused more impacts to non-target plants than triclopyr. Both selective and non-selective imazapyr applications resulted in chlorosis, stunting, and deformity of shrubs and forbs one year after treatment. This suggests imazapyr can remain active in northern soils for at least 365 days as well as transfer to untreated plants. The range of sensitivities of boreal plant species to imazapyr and triclopyr and potential persistence in northern soils highlights the need for focused toxicity research in the North.

Key Words. Canada; Imazapyr; Integrated Vegetation Management; Right-of-Way; Succession; Triclopyr; Yukon.
\end{abstract}

Electrical utility rights-of-way (ROWs) present demanding challenges for vegetation management as safe, reliable electrical service is compromised by trees near or underneath transmission lines. An extensive range of mechanical, chemical, and biological methods are available to vegetation managers and are allowing for more complex management regimes. Rather than simply "resetting" succession to a previous stage, management methods can be designed to alter the plant species and abiotic conditions on a ROW, and thus fundamentally change the direction of plant community development (Rosenberg and Freedman 1984; Niering 1987; Pickett et al. 2009). Certain low-growing plant communities or "cover types" have been proven to reduce tree establishment on ROWs, and strategic management can facilitate their development (Bramble et al. 1991; Meilleur et al. 1994; Yahner and Hut- nik 2004; McLoughlin 2014). Integrated vegetation management (IVM) encompasses the systematic approach of understanding and manipulating ROW plant communities to meet management objectives with minimum cost and environmental impact (Nowak and Ballard 2005).

A key component of IVM is understanding local vegetation dynamics, especially identifying low-growing plant communities that resist the re-growth of trees and the techniques that encourage the formation of such communities (Niering 1987; Nowak and Ballard 2005). In southern jurisdictions, maintaining or enhancing shrub cover is the most effective method of inhibiting target species establishment; this objective is typically achieved by selective herbicide application to individual tree and tall shrub stems or foliage (Niering and Goodwin 1974; Dreyer and Niering 1986; Bramble et al. 1991; Meilleur et al. 1994; 
Yahner and Hutnik 2004). A modern example of IVM successfully promoting shrub communities exists in New York State, where the use of selective herbicide applications on power line ROWs has been mandated since the 1980s (McLoughlin 2014). Whether IVM principles and selective herbicide techniques will produce similar results in northern boreal ecosystems has not been tested.

The Yukon Territory, in northern Canada, is dominated by boreal forests and has over 1000 $\mathrm{km}$ of power line ROWs that have traditionally been cleared by mowing and brushing. The use of herbicide for woody plant control is not common in the area and knowledge of the effectiveness and non-target impacts of herbicides under local conditions is lacking. In addition, it is unclear how herbicide dissipation rates will be affected by the cold climate. Dissipation pathways are primarily via photochemical and soil microbial degradation, which are strongly regulated by both climatic conditions and soil properties. The diversity and abundance of microorganisms that act on the herbicide residues are impacted by soil temperature and moisture content. While slower rates of degradation may be expected in dry, cold northern soils, there is evidence that northern soil microbes can metabolize herbicides at lower temperatures than reported elsewhere (Newton et al. 2008). In addition, the impact of extended photoperiods on rates of photochemical degradation at more northern latitudes remains unclear.

Herbicide use is a potential tool for Yukon ROWs, as many products are registered for the most common target species requiring management: trembling aspen (Populus tremuloides), balsam poplar (Populus balsamifera), and willows (Salix spp.). Aspen and poplar are well-known for aggressive suckering after aboveground disturbance (Frey et al. 2003; Ilisson and Chen 2009); willows, such as Salix bebbiana, are clonal and common in disturbed areas (Amiro and Courtin 1981; Carleton and MacLellan 1994). The abundance of these target species on Yukon ROWs and their life histories strongly indicate that mechanical treatments do not promote the development of plant communities resistant to these species. It is difficult to predict which treatments and subsequent cover types may be most advantageous, as there are no examples of long-term IVM programs in northern boreal regions, as of this research.

Desirable shrub species on ROWs have been documented in eastern North America (e.g., Ballard et al. 2011), but there are few shared species between eastern deciduous and northern boreal forests. Nevertheless, many northern shrubs share characteristics, such as clonal growth and heliophily that have been linked to the formation of dense cover (Meilleur et al. 1994). Stable low-growing shrub communities occur in many ecosystems worldwide (Royo and Carson 2006), and it is likely a boreal equivalent exists.

In addition to shrub cover types, aggressive perennial grasses may provide a solution as they are well-documented competitors of tree seedlings in the northern forestry industry (Ballandier et al. 2006). The roots and litter of bluejoint reedgrass (Calamagrostis canadensis), for example, can directly suppress aspen seedling and sucker development by maintaining cooler soil temperatures and physically preventing sucker penetration through the soil (Landhäusser and Lieffers 1998; Landhäusser et al. 2007). Similarly, orchardgrass (Dactylis glomerata) can outcompete tree species on ROWs if seeded immediately after mowing (Brown 1995). Exploiting natural competitive interactions by planting aggressive native grasses may be facilitated through selective herbicide applications, direct seeding, or a combination of both.

The objectives of this study were to 1) assess the effectiveness of eight ROW management treatments, including selective and non-selective herbicide applications and native grass seeding; 2) evaluate the impacts of herbicide applications on non-target vegetation; and 3) examine treatment-induced changes to plant community composition and structure.

\section{METHODS}

\section{Study Area}

Four study sites were located on power line ROWs in Yukon, Canada. Sites were distributed across the territory within the Boreal Cordillera Ecozone and were representative of the ecotypes where ROWs are found (Table 1). Sites were 
selected for the study by aerial survey to ensure homogeneity of vegetation type and similar development since the last mowing cycle. Located in the southwest portion of the territory, HJ1 and $\mathrm{HJ} 2$ were approximately $20 \mathrm{~km}$ apart, with the more centrally located CAR site approximately $170 \mathrm{~km}$ to the north. The DAW site was the most northern site, located approximately 350 $\mathrm{km}$ northwest of CAR. The three more southern sites (CAR, HJ1, and HJ2) were bordered by midsuccessional boreal forests dominated by white spruce (Picea glauca) and trembling aspen (Populus tremuloides), and the more northern DAW site bisected a mature coniferous stand (Picea spp.). Dominant vascular plant covers on the ROWs prior to application are summarized in Table 2.

Yukon's climate is classified as subarctic continental, with precipitation at lower elevations ranging from $250-300 \mathrm{~mm}$ annually (Smith et al. 2004). Weather conditions for each site were obtained from the nearest Yukon Wildland Fire Management stations and compared to 30-year Environment Canada Climate Normals (19812010) for the regions (Table 3). Overall, conditions were within normal ranges, though above average May temperatures occurred across the territory in 2015 and resulted in an early spring. The DAW site experienced more precipitation than normal both seasons, but the elevation difference between the Antimony and Dawson A stations $(\sim 170 \mathrm{~m})$ likely contributed to the difference; precipitation typically increases with elevation in Yukon (Smith et al. 2004).

\section{Sampling Design}

Each of the four sites was laid out in a randomized complete block design. At each site, three blocks with eight randomly assigned treatment plots per block were installed. Blocking was used to account for variation in site conditions (e.g., slope, aspect, soil moisture). The $6 \mathrm{~m} \times 6 \mathrm{~m}$ treatment plots were spaced at a minimum of $50 \mathrm{~m}$ apart to avoid interference between treatments (i.e., herbicide drift). Treatments were applied uniformly across the $6 \mathrm{~m} \times 6 \mathrm{~m}$ plot. Within each treatment plot, four $1 \mathrm{~m}^{2}$ permanent vegetation cover plots were established and percent cover data recorded before treatments were applied in July 2014. Total percent cover of each species was recorded to the nearest percentage and all unknown species were collected from outside the plot for later identification. Vegetation cover was recorded again in 2015 within ten days of the original observation dates. Prior to analyses the average cover values for each treatment plot were determined from the four permanent vegetation cover plots.

Eight treatments were designed to represent mechanical, chemical, and biological strategies for ROW vegetation management (Table 4). The control was mechanical mowing, the current standard treatment, which was simulated by hand cutting all vegetation at $10-20 \mathrm{~cm}$ above the soil surface. Two common products used for woody species control were selected: Garlon ${ }^{\circledR}$ XRT (755 g/L triclopyr butoxyethyl ester; Dow AgroSciences Canada Inc., Calgary, Alberta, Canada) and Arsenal $^{\circledR}$ PowerLine $^{\text {tw }}$ (240 g/L imazapyr acid; BASF Canada

Table 1. Location and description of right-of-way vegetation management study sites in Yukon. Climate data is from Environment Canada Climate Normals (1981-2010) for Mayo Road (CAR), Dawson Airport (DAW), and Otter Falls (HJ1 and HJ2). Soil classification was derived from White et al. (1992).

\begin{tabular}{|c|c|c|c|c|c|c|c|}
\hline Site & Coordinates & Ecoregion & $\begin{array}{l}\text { Mean annual } \\
\text { precip. (mm) }\end{array}$ & $\begin{array}{l}\text { Mean January } \\
\text { temp. }\left({ }^{\circ} \mathrm{C}\right)\end{array}$ & $\begin{array}{l}\text { Mean July } \\
\text { temp. }\left({ }^{\circ} \mathrm{C}\right)\end{array}$ & Soil type & $\begin{array}{l}\text { Year of last } \\
\text { mowing treatment }\end{array}$ \\
\hline CAR & $\begin{array}{l}61.8^{\circ} \mathrm{N}, 136.0^{\circ} \mathrm{W} \\
61.9^{\circ} \mathrm{N}, 136.1^{\circ} \mathrm{W}^{\mathrm{z}}\end{array}$ & Yukon Plateau - Central & 323.4 & -17.2 & 14.9 & $\begin{array}{l}\text { Eutric Brunisol } \\
\text { on sand }\end{array}$ & 2010 \\
\hline DAW & $63.9^{\circ} \mathrm{N}, 138.4^{\circ} \mathrm{W}$ & $\begin{array}{l}\text { Yukon Plateau - North } \\
\text { /Klondike Plateau }\end{array}$ & 324.3 & -26.0 & 15.7 & $\begin{array}{l}\text { Eutric Brunisol } \\
\text { on sand }\end{array}$ & 2008 \\
\hline HJ1 & $60.8^{\circ} \mathrm{N}, 136.6^{\circ} \mathrm{W}$ & Yukon Southern Lakes & 297.3 & -16.1 & 13.0 & $\begin{array}{l}\text { Eutric Brunisol } \\
\text { on clay loam }\end{array}$ & 2013 \\
\hline HJ2 & $60.8^{\circ} \mathrm{N}, 136.0^{\circ} \mathrm{W}$ & Yukon Southern Lakes & 297.3 & -16.1 & 13.0 & $\begin{array}{l}\text { Eutric Brunisol } \\
\text { on clay loam }\end{array}$ & 2011 \\
\hline
\end{tabular}

${ }^{\mathrm{z}}$ The CAR site was composed of two blocks at one access, and one block $10 \mathrm{~km}$ north, to avoid surface water drainages. 
Table 2. Average percent cover of dominant vegetation on four Yukon ROW sites prior to treatment in 2014, and the average absolute reduction in cover one year after eight management techniques. Treatment codes are described in Table 4. A detailed species list will be available online (Isbister 2016).

\begin{tabular}{|c|c|c|c|c|c|c|c|c|c|c|}
\hline \multirow[t]{2}{*}{ Site } & \multirow[t]{2}{*}{ Dominant species in 2014} & \multirow{2}{*}{$\begin{array}{l}\text { Average } \% \text { cover of } \\
\text { site before treatment }\end{array}$} & \multicolumn{8}{|c|}{ Reduction in cover (\% of plot area) after application (2015) } \\
\hline & & & BS-T & BS-I & CS-T & CS-I & PI-T & PI-I & SC & MC \\
\hline \multirow[t]{6}{*}{ CAR } & Picea glauca & 18.4 & -11.7 & -6.5 & -14.7 & -12.9 & 13.4 & -2.4 & 10.8 & -4.5 \\
\hline & Populus tremuloides & 14.2 & -10.3 & -16.8 & -20.8 & -11.6 & -12.3 & -16.1 & -11.5 & -12.3 \\
\hline & Rosa acicularis & 6.1 & -9.7 & -3.8 & -7.6 & -11.0 & -4.7 & -8.5 & -7.8 & -2.0 \\
\hline & Linnaea borealis & 8.7 & -2.3 & -16.8 & 4.8 & -1.3 & -2.6 & -6.9 & 4.9 & 1.8 \\
\hline & Chamerion angustifolium & 7.0 & -2.8 & -2.8 & -0.8 & -2.0 & -7.3 & -3.1 & -5.5 & 1.6 \\
\hline & Calamagrostis purpurascens & 13.3 & -0.9 & -14.8 & -5.3 & -23.4 & -4.3 & -7.4 & -4.8 & -9.9 \\
\hline \multirow[t]{8}{*}{ DAW } & Betula neoalaskana & 7.3 & -14.8 & -2.4 & -6.0 & -9.6 & -6.0 & -14.1 & -1.8 & -6.0 \\
\hline & Salix spp. & 13.9 & -2.4 & -14.0 & -1.5 & -13.2 & -8.6 & -24.6 & -8.7 & -3.7 \\
\hline & Vaccinium uliginosum & 10.0 & -6.0 & -13.2 & 5.9 & -16.4 & 17.4 & 0.8 & 1.3 & -1.4 \\
\hline & Rhododendron groenlandicum & 8.0 & 3.0 & 2.6 & 1.5 & -8.0 & 6.0 & -0.8 & 2.5 & -1.8 \\
\hline & Vaccinium vitis-idaea & 6.1 & -3.3 & -1.6 & -0.6 & -2.2 & -3.4 & -2.6 & -0.4 & -1.4 \\
\hline & Cornus canadensis & 11.1 & -9.4 & -8.1 & -7.3 & -17.4 & 3.6 & 0.8 & -3.6 & 0.2 \\
\hline & Chamerion angustifolium & 6.0 & -2.9 & -3.1 & -0.5 & -3.6 & -2.3 & -1.7 & -3.2 & -3.2 \\
\hline & Festuca altaica & 7.7 & -0.9 & 2.0 & 5.8 & -5.8 & -0.6 & -6.4 & 0.5 & 1.3 \\
\hline \multirow[t]{5}{*}{$\mathrm{HJ1}$} & Populus tremuloides & 6.4 & -2.0 & -3.6 & -15.4 & -1.8 & -1.0 & -2.7 & -3.7 & -3.0 \\
\hline & Arctostaphylos uva-ursi & 37.0 & -41.5 & -7.0 & 3.3 & 2.4 & 0.4 & -1.3 & -6.7 & -13.3 \\
\hline & Chamerion angustifolium & 4.4 & -0.5 & -3.8 & -7.5 & 0.3 & 2.8 & -1.4 & - & -1.5 \\
\hline & Calamagrostis purpurascens & 7.8 & 0.6 & -8.2 & 4.1 & 0.7 & -0.3 & -2.3 & -0.8 & 1.0 \\
\hline & Bromus pumpellianus & 3.7 & 0.4 & -7.7 & -1.0 & 0.3 & 0.5 & -1.2 & -2.4 & -4.8 \\
\hline \multirow[t]{6}{*}{$\mathrm{HJ} 2$} & Populus tremuloides & 17.4 & -14.1 & -25.3 & -13.0 & -26.3 & -4.6 & -7.5 & -17.8 & -13.4 \\
\hline & Salix spp. & 13.9 & -33.1 & -23.1 & -12.4 & 0.8 & -7.1 & -10.0 & -17.4 & -14.4 \\
\hline & Shepherdia canadensis & 11.6 & -7.4 & -10.6 & -0.5 & -11.4 & -1.3 & -9.6 & 5.0 & -0.5 \\
\hline & Arctostaphylos uva-ursi & 10.2 & 5.0 & -0.9 & 2.3 & 20.0 & -21.9 & -7.8 & -1.5 & -0.5 \\
\hline & Fragaria virginiana & 10.4 & -6.0 & -3.8 & 0.3 & -0.3 & -4.9 & -2.1 & -0.1 & -1.5 \\
\hline & Calamagrostis purpurascens & 7.8 & 4.2 & -7.8 & -2.3 & -5.1 & -1.9 & -21.4 & -1.3 & -5.0 \\
\hline
\end{tabular}

Table 3. Average summer daily temperatures and total precipitation during the 2014/2015 study period near four Yukon ROW study sites in comparison to 1981-2010 climate normals for each region.

\begin{tabular}{|c|c|c|c|c|c|c|c|c|c|c|c|c|c|c|c|}
\hline \multirow[t]{3}{*}{ Data source } & \multirow[t]{3}{*}{ Station } & \multirow[t]{3}{*}{ Coordinates } & \multirow{3}{*}{$\begin{array}{l}\text { Elevation } \\
(\mathrm{m})\end{array}$} & \multicolumn{6}{|c|}{ Average daily temperature $\left({ }^{\circ} \mathrm{C}\right)$} & \multicolumn{6}{|c|}{ Average total precipitation (mm) } \\
\hline & & & & \multicolumn{3}{|c|}{2014} & \multicolumn{3}{|c|}{2015} & \multicolumn{3}{|c|}{2014} & \multicolumn{3}{|c|}{2015} \\
\hline & & & & Jul. & Aug. & Sep. & May & Jun. & Jul. & Jul. & Aug. & Sep. & May & Jun. & Jul. \\
\hline $\begin{array}{l}\text { Yukon Wildland } \\
\text { Fire Management }\end{array}$ & Antimony & $64.0^{\circ} \mathrm{N}, 138.6^{\circ} \mathrm{W}$ & 544 & 15.0 & 12.0 & 5.2 & 13.0 & 14.0 & 14.6 & 53.4 & 59.8 & 36.6 & 61.2 & 60.5 & 81.0 \\
\hline $\begin{array}{l}\text { Environment } \\
\text { Canada 1981-2000 } \\
\text { Normals }\end{array}$ & Dawson A & $64.0^{\circ} \mathrm{N}, 139.1^{\circ} \mathrm{W}$ & 370 & 15.7 & 12.3 & 5.8 & 8.2 & 14.0 & 15.7 & 49.0 & 43.4 & 34.0 & 30.8 & 38.2 & 49.0 \\
\hline $\begin{array}{l}\text { Yukon Wildland } \\
\text { Fire Management }\end{array}$ & Braeburn & $61 .^{\circ} 5 \mathrm{~N}, 138.8^{\circ} \mathrm{W}$ & 725 & 14.6 & 12.3 & 6.0 & 11.1 & 13.0 & 14.0 & 47.8 & 30.6 & 64.8 & 16.7 & 43.5 & 66.2 \\
\hline $\begin{array}{l}\text { Environment } \\
\text { Canada 1981-2000 } \\
\text { Normals }\end{array}$ & Mayo Road & $60.9^{\circ} \mathrm{N}, 138.2^{\circ} \mathrm{W}$ & 655 & 14.9 & 12.8 & 7.1 & 7.7 & 12.9 & 14.9 & 51.0 & 47.9 & 35.9 & 25.3 & 39.0 & 51.0 \\
\hline $\begin{array}{l}\text { Yukon Wildland } \\
\text { Fire Management }\end{array}$ & Champagne & $60.8^{\circ} \mathrm{N}, 136.4^{\circ} \mathrm{W}$ & 756 & 14.3 & 12.5 & 6.7 & 11.2 & 13.5 & 14.3 & 52.0 & 34.0 & 98.8 & 8.4 & 39.4 & 31.4 \\
\hline $\begin{array}{l}\text { Environment } \\
\text { Canada 1981-2000 } \\
\text { Normals }\end{array}$ & Otter Falls & $61.0^{\circ} \mathrm{N}, 137.1^{\circ} \mathrm{W}$ & 830 & 13.0 & 10.8 & 5.8 & 5.9 & 10.9 & 13.0 & 54.5 & 43.1 & 31.0 & 21.0 & 43.7 & 54.5 \\
\hline
\end{tabular}

Inc., Mississauga, Ontario, Canada). Selection of these herbicides was based upon a targetsuitability and risk-level assessment, as well as favorable performance on target species in a 2014 pilot study conducted by a local consulting company (EDI 2013). The two herbicides were applied through three methods: broadcast spray, cut stump, and point injection at the maximum rates specified on the labels (broadcast spray: $4530 \mathrm{~g}$ triclopyr/ha, $720 \mathrm{~g}$ imazapyr/ha; cut 
stump and point injection: $143.5 \mathrm{~g}$ triclopyr/L canola oil, $22.6 \mathrm{~g}$ imazapyr/L DI water). A handpressurized backpack sprayer with an adjustable poly tip and brass nozzle was used for the broadcast spray treatment (Stanley 61804 Poly 4 Gallon Professional Backpack Sprayer). Cut-stump applications were completed by hand cutting all vegetation at $20-30 \mathrm{~cm}$ and applying products to all cut stems with a paint brush. Point injections were applied via syringe and inserted into a small, drilled hole or incision in the stem of a target species. For all imazapyr treatments Hasten $^{\mathrm{Tx}}$ Spray Adjuvant (704 $\mathrm{g} \mathrm{L}^{-1}$ Ethyl and Methyl esters of vegetable oil with $196 \mathrm{~g} \mathrm{~L}^{-1}$ non-ionic surfactants; Victorian Chemicals Group, Victoria, Australia) was added to application solutions at a rate of $0.25 \%$. In selective cutting plots, only target species were hand cut and removed. Point injection and selective cutting plots were also seeded with native grasses at $50 \mathrm{~kg} / \mathrm{ha}$, as high seeding rates have been shown to reduce species invasion of disturbed areas in Yukon (EDI 2009). Litter was raked out of the plot to prepare the seed bed, and a native grass seed mix of $42 \%$ (b/wt) violet wheatgrass (Elymus violaceus), $26 \%$ slender wheatgrass (Elymus trachycaulus), 8\% rocky mountain fescue (Festuca saximontana), 6\% glaucous bluegrass (Poa glauca), 5\% bluejoint reedgrass (Calamagrostis canadensis), and 2\% tufted hairgrass (Deschampsia caespitosa) from DLF Pickseed Canada (Lindsay, Ontario, Canada) was broadcast by hand. After seeding, the plot was lightly raked to ensure good seed-soil contact. Treatments were applied between mid-July and early August 2014.

Target species were defined based on two criteria: rapid re-growth after disturbance and the ability to grow tall enough to interfere with transmission lines. Trembling aspen, balsam poplar, and willows were present at every site, and Alaska paper birch (Betula neoalaskana) was included at the DAW site. While conifers in the Yukon Territory can grow to a height where they may interfere with lines, due to their very slow growth rates, conifers are not considered a management concern by the utility company and were thus not included as target species.

Visual damage assessments were completed one year after application in all chemically treated plots. Targets were evaluated by species, and the damage to treated stems and new suckers/seedlings were separated to identify duration of effect. Non-targets were assessed by life-form: erect shrubs ( $<1.5 \mathrm{~m}$ in height), prostrate shrubs, forbs, and graminoids. A scale of $0-100$ was used, with 0 being unaffected and 100 being completely dead. Only herbicide-related damage was recorded. Untreated areas surrounding the plot were used as a reference to differentiate between natural and herbicide damage.

Species richness and evenness were determined for each treatment plot, using the average cover and total number of species from the four vegetation cover subplots. Species richness was defined as the total number of species per plot. Evenness was calculated with the EVar index based on the average percent cover of each species per plot (Smith and Wilson 1996).

\section{Statistical Analysis}

Treatment effects on the responses of target and non-target species, species richness, and species evenness were analyzed via linear mixed-models using the $\mathrm{R}$ library "lmerTest"

Table 4. Description of eight right-of-way vegetation management treatments applied in four sites within Yukon in 2014.

\begin{tabular}{|c|c|c|c|}
\hline Treatment & Abbreviation & Strategy & Description \\
\hline Mowing (control) & MC & Mechanical & Cut and removed all vegetation at $10-20 \mathrm{~cm}$ above soil surface. \\
\hline Broadcast Spray - Triclopyr & BS-T & Chemical & \multirow{2}{*}{$\begin{array}{l}\text { Applied herbicide with a backpack sprayer to all vegetation; any } \\
\text { stems above } 1.5 \mathrm{~m} \text { were cut prior to spraying. }\end{array}$} \\
\hline Broadcast Spray - Imazapyr & BS-I & Chemical & \\
\hline Cut Stump - Triclopyr & CS-T & Chemical & \multirow{2}{*}{$\begin{array}{l}\text { Cut all vegetation at } 20-30 \mathrm{~cm} \text { above soil surface and applied } \\
\text { herbicide with a paintbrush. }\end{array}$} \\
\hline Cut Stump - Imazapyr & CS-I & Chemical & \\
\hline Point Injection - Triclopyr & PI-T & Chemical/Biological & \multirow{2}{*}{$\begin{array}{l}\text { Incised small stems/drilled large stems of targets only and } \\
\text { applied herbicide with a syringe; seeded native grasses. }\end{array}$} \\
\hline Point Injection - Imazapyr & PI-I & Chemical/Biological & \\
\hline Selective Cutting & SC & Mechanical/Biological & Hand cut and removed targets; seeded native grasses. \\
\hline
\end{tabular}


(Kuznetsova et al. 2014). Assumptions of normality and equal variance were checked post hoc with QQ plots and fitted versus residual plots. If significant $(\alpha=0.05)$, differences between least squared means of each factor combination were generated by function "difflsmeans" and sorted to assess differences within factors.

Efficacy of target species control by treatment was assessed by converting 2014 and 2015 abundance data into percent control: [(2014 cover - 2015 cover $) / 2014$ cover $] * 100$. An increase in cover post-treatment was truncated at 0 for "no control." Data points with $<1 \%$ cover of a target species in 2014 were removed from the analysis, as even the most marginal change generated large percent control values and dominated the analysis. Prior to modelling, percent-control data were power transformed $(\lambda=2)$ to stabilize the variance and meet normality assumptions of linear mixed-models. Treatment, species, and their interaction were fixed factors, with site and block as random variables.

Non-target species abundances were grouped by life-form: erect shrubs, prostrate shrubs, forbs, and graminoids. Conversion to proportions of 2014 cover overemphasized small changes by life-forms with minimal cover. For example, life-forms with 3\% cover in 2014 and $2 \%$ cover in 2015 would have decreased by $\sim 30 \%$, which exaggerates the change's significance. The absolute difference in cover between 2014 and 2015 was thus selected as the response variable for non-target species to better represent the magnitudes of changes. Treatment, life-form, and their interaction were included as fixed effects, and site and block were random variables.

To test for herbicide by application-type interactions, treatments were separated into herbicide and application-type factors. Damage values were $\log (\mathrm{x}+1)$ transformed prior to analysis to meet assumptions of equal variance and normality of model residuals. Target and non-target vegetation were again modeled separately. Damage analysis for target species included four main factors (i.e., age, herbicide, application type, and species) and all potential interactions. Age accounted for the difference between treated stems and newly sprouted seedlings or suckers. The model for non-targets tested herbicide, appli- cation type, life-form, and their interactions as fixed factors. Both damage assessment models included site and block as random variables.

The species richness and evenness models included treatment, site, and their interaction as fixed factors, and block as the random variable. Data from before treatment and one year after were modeled separately. Tests for treatment effects on community composition one year after treatment were made using PERMANOVA with Bray-Curtis distances in R library "vegan" (Oksanen et al. 2015). PERMANOVA is a nonparametric multivariate analysis of variance using distance matrices that can incorporate complex experimental designs (Anderson 2001). Treatment, site, and a treatment:site interaction were fixed effects in the analysis, with species abundance data one year following treatment as the response. The analysis was stratified by block with 999 permutations. The assumption of similar dispersion was checked post hoc and both treatment and site data were within acceptable ranges ( $P$ values of 0.67 and 0.06 )

All statistical analyses were completed in $\mathrm{R}$ version 3.1.2 ( $\mathrm{R}$ Core Team 2015).

\section{RESULTS}

\section{Control of Target Species}

Control of target species one year following treatment was greater in most chemically treated plots than after selective cutting and mechanical mowing (ANOVA, $\mathrm{F}_{7,118}=4.29, P$ $<0.01)$. Imazapyr broadcast spray provided the greatest control, and mowing was the least effective (Figure 1). One target species was not more sensitive to treatments than others $\left(\mathrm{F}_{3115}\right.$ $=0.67, P=0.93)$, and there was also no species by treatment interaction $\left(\mathrm{F}_{20,118}=0.91, P\right.$ $=0.50$ ). Imazapyr was only more effective than triclopyr when applied by broadcast spraying $(94 \% \pm 1.7 \mathrm{SE}, \mathrm{n}=21$ versus $82 \% \pm 7.6 \mathrm{SE}, \mathrm{n}=$ 17 , where $\mathrm{n}$ are treatment plots) and both herbicides provided equivalent control in cut-stump and point-injection plots. Cut stump with triclopyr was the least effective chemical treatment and was not different from selective cutting.

In general, imazapyr caused more damage to target species than triclopyr; however, this dif- 
ference was only measured in damage to new seedlings and suckers. Mean damage values to the previous year's treated stems by imazapyr and triclopyr were $95 \pm 1.2 \mathrm{SE}, \mathrm{n}=74$, and $95 \pm$ $1.5 \mathrm{SE}, \mathrm{n}=76$ (out of 100 ), respectively, whereas growth in imazapyr plots had more residual herbicide damage than triclopyr (Table 5). Damage was greater for plants that were directly treated than for those that emerged the following growing season (Age). Directly treated birch (98 \pm 1.0SE, $\mathrm{n}=16)$ and aspen $(98 \pm 1.2 \mathrm{SE}, \mathrm{n}=56)$ were more damaged than poplar $(93 \pm 2.9 \mathrm{SE}, \mathrm{n}$ $=30$ ), but similar to willows $(93 \pm 1.8 \mathrm{SE}, \mathrm{n}=$ 48). Damage to new growth was comparable among most species and the only difference was greater damage to willows $(13 \pm 3.6 \mathrm{SE}, \mathrm{n}=$ $33)$ compared with aspen $(10 \pm 2.1 \mathrm{SE}, \mathrm{n}=54)$.

\section{Response of Non-Target Vegetation}

Most treatment applications resulted in a neutral or negative change in non-target vegetation cover after one year (ANOVA, $\mathrm{F}_{7,314}=5.47, P<$ $0.01)$. Treatments rarely caused cover changes greater than $\pm 10 \%$ of the plot area and no distinct trends across vegetative life-forms (i.e., erect shrubs, prostrate shrubs, forbs, and graminoids) were detected. Treatment effects on cover change were life-form-specific, as demonstrated by a very strong interaction among life-form and treatment $\left(\mathrm{F}_{21,314}=2.74, P<0.01\right.$; Figure 2$)$. Visual herbicide damage assessments indicated imazapyr was more damaging than triclopyr, with main effects of herbicide, application type, lifeform, and most two-way interactions significant (Table 5). In non-target species, damage by application type was consistent with the selectivity of the method: broadcast spray caused more damage, followed by cut stump

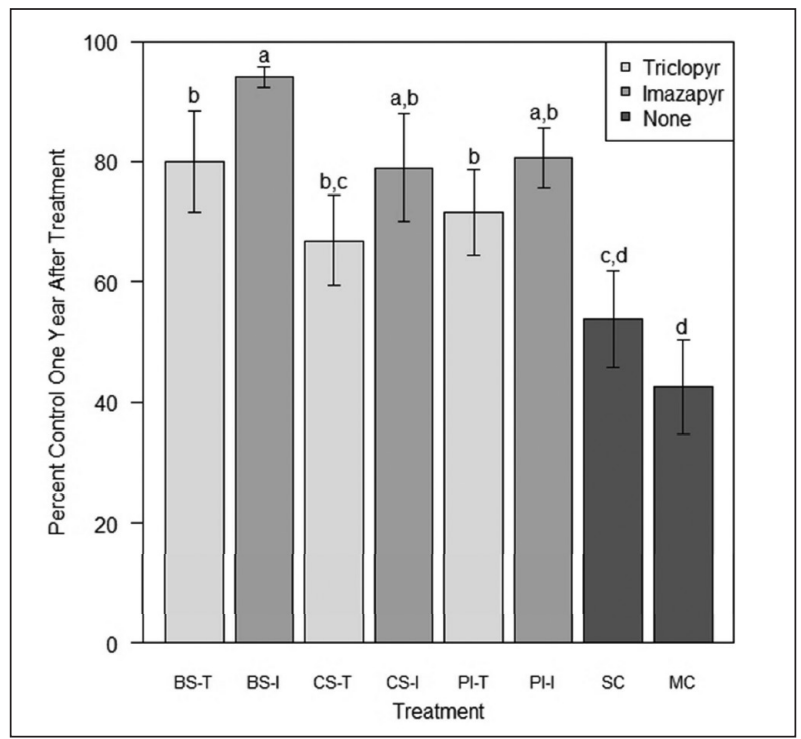

Figure 1. Control of target species on Yukon ROWs one year after eight vegetation management treatments. Percent control is defined as the difference in cover between 2014 and 2015, divided by 2014 cover $\times 100$. Shading indicates type of herbicide, and treatment codes are described in Table 4. Error bars represent standard error with $n=17,21,19,16,22$, 26, 16, and 15 for each treatment. Different letters indicate statistically significant differences between least square means $(P<0.05)$

Table 5. Linear mixed-model summaries for herbicide damage (0-100) to target species and non-target vegetation one year after right-of-way vegetation management treatments. Non-target life-forms were erect shrubs ( $<1.5 \mathrm{~m}$ high), prostrate shrubs, forbs, and graminoids. Both models tested herbicide (H), application type (AT), species or life-form (SP/LF), and all interactions as factors. Age (AG) was also tested as a factor influencing damage to target species and had two levels: directly treated in $\mathbf{2 0 1 4}$ or newly sprouted seedling/sucker in 2015. Models included site and block as random variables.

\begin{tabular}{lll}
\hline Source & Target species & Non-target life forms \\
\hline Age $(\mathrm{AG})$ & $\mathrm{F}_{1,220}=1726.51, P<0.01$ & $\mathrm{~F}_{1,214}=213.91, P<0.01$ \\
Herbicide (H) & $\mathrm{F}_{1,224}=14.89, P<0.01$ & $\mathrm{~F}_{2,217}=43.79, P<0.01$ \\
Application type (AT) & $\mathrm{F}_{2,224}=1.39, P=0.25$ & $\mathrm{~F}_{3,215}=22.24, P<0.01$ \\
Species/Life-form (SP/LF) & $\mathrm{F}_{3,226}=1.41, P=0.23$ & $\mathrm{~F}_{1,218}=15.15, P<0.01$ \\
AG $\times$ H & $\mathrm{F}_{2,220}=0.96, P=0.39$ & $\mathrm{~F}_{2,214}=0.97, P=0.38$ \\
AG $\times$ AT & $\mathrm{F}_{3,220}=3.97, P<0.01$ & $\mathrm{~F}_{3,214}=5.89, P<0.01$ \\
AG $\times$ SP & $\mathrm{F}_{2,221}=1.65, P=0.19$ & $\mathrm{~F}_{6,214}=3.26, P<0.01$ \\
$\mathrm{H} \times \mathrm{AT}$ & $\mathrm{F}_{3,224}=1.34, P=0.26$ & \\
$\mathrm{H} \times \mathrm{SP} / \mathrm{LF}$ & $\mathrm{F}_{6,224}=2.01, P=0.07$ & \\
$\mathrm{AT} \times \mathrm{SP} / \mathrm{LF}$ & $\mathrm{F}_{2,220}=2.06, P=0.13$ & \\
$\mathrm{AG} \times \mathrm{H} \times \mathrm{AT}$ & $\mathrm{F}_{3,220}=0.16, P=0.92$ & \\
$\mathrm{AG} \times \mathrm{H} \times \mathrm{SP} / \mathrm{LF}$ & $\mathrm{F}_{6,221}=0.57, P=0.75$ & $\mathrm{~F}_{6,214}=9.08, P<0.01$ \\
$\mathrm{AG} \times \mathrm{AT} \times \mathrm{SP} / \mathrm{LF}$ & $\mathrm{F}_{6,223}=0.37, P=0.90$ & \\
$\mathrm{H} \times \mathrm{AT} \times \mathrm{SP} / \mathrm{LF}$ & $\mathrm{F}_{6,220}=0.93, P=0.47$ & \\
$\mathrm{AG} \times \mathrm{H} \times \mathrm{AT} \times \mathrm{SP} / \mathrm{LF}$ & &
\end{tabular}


and point injection (Figure 3). Life-form was a significant factor in explaining visual damage, with erect shrubs being the most sensitive.

Erect-shrub cover was reduced one year after treatment in all plots except triclopyr point injection and selective cutting. The impacts of chemical treatments were dependent on herbicide type. Broadcast spray treatments resulted in similar decreases in cover of erect shrubs, but visual damage by imazapyr was greater (Figure 3). Cut-stump with imazapyr treatments reduced plot cover by more than $15 \%$ and damage was high ( $62 \pm 10.13 \mathrm{SE}, \mathrm{n}=6)$, but only minor cover reduction and damage was measured in triclopyr cut-stump plots. Although point-injection treatments were only applied to target species, nontarget erect-shrub cover was affected by the type of herbicide: cover increased in point injection with triclopyr plots $(+5.53 \% \pm 5.4 \mathrm{SE}, \mathrm{n}=9)$ and decreased in imazapyr point-injection plots $(-5.7 \%$ $\pm 3.1 \mathrm{SE}, \mathrm{n}=10)$. This was consistent with damage assessments; triclopyr point injection caused almost 0 visual damage compared to imazapyr

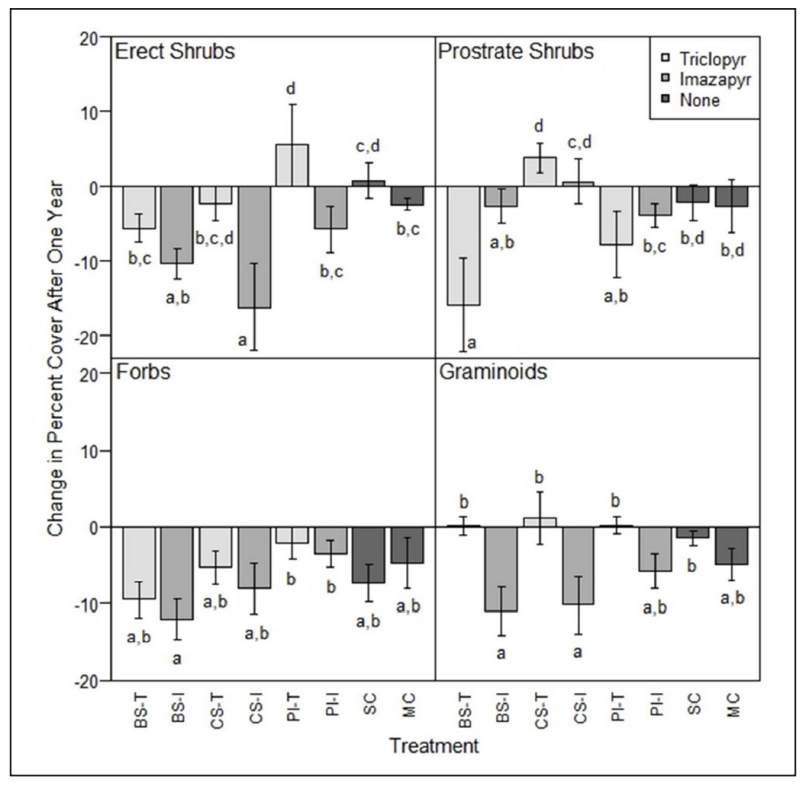

Figure 2. Change in non-target vegetation cover by life-form one year after eight ROW vegetation management treatments in Yukon. Bars represent the difference in percent cover between 2014 and 2015. Shading indicates type of herbicide applied, and treatment codes are described in Table 4 . Error bars represent standard error and for erect shrubs: $\mathbf{n}$ $=11,9,10,8,9,10,8$, and 12; prostrate shrubs: $n=11,11,12$, $10,10,11,11$, and 11 . For both forbs and graminoids: $n=12$ across all plots. Different letters indicate statistically significant differences between least square means $(P<0.05)$.

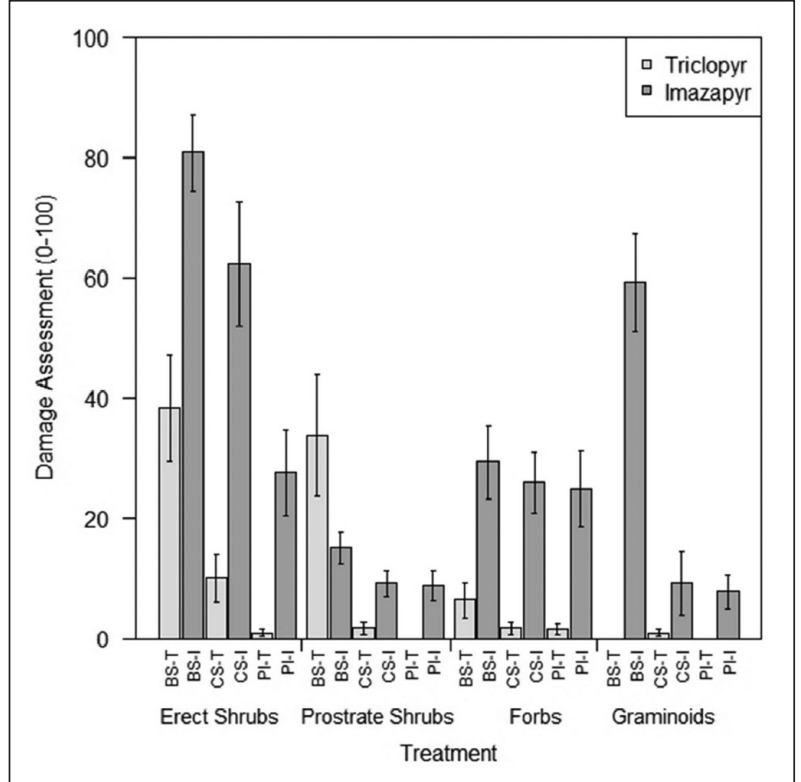

Figure 3. Herbicide damage to non-target vegetation one year after eight ROW vegetation management treatments in Yukon. Mean damage assessment values $(0-100)$ are grouped by life-form, and shading indicates the different herbicides used. Treatment codes are described in Table 4. Error bars represent standard error, and for erect shrubs: $\mathbf{n}$ $=11,7,9,6,8$, and 10; prostrate shrubs: $n=11,12,11,9,10$, and 10; forbs: $n=12,12,11,11,11$, and 11 ; and graminoids: $\mathrm{n}=12,12,11,11,11,11$.

$(27.5 \pm 7.19 \mathrm{SE}, \mathrm{n}=10)$. As imazapyr was not point injected into erect shrubs, transfer occurred by way of an unknown belowground mechanism. There was no change in erect-shrub cover in selective-cutting plots and mowing treatments resulted in a minor decrease of $2.4 \%( \pm 0.9 \mathrm{SE}, \mathrm{n}=12)$.

Prostrate-shrub cover did not change substantially after most treatments, except for broadcast spray with triclopyr, which reduced cover by $15.9 \%$ $( \pm 6.2 \mathrm{SE}, \mathrm{n}=11)$. In contrast, prostrate shrubs were only slightly impacted by imazapyr spray $(-2.6 \% \pm$ 2.3SE, $\mathrm{n}=11$ ) and damage assessment values were also low $(15 \pm 2.61 \mathrm{SE}, \mathrm{n}=12)$. Cut-stump treatments caused a weak $(<5 \%)$ increase in cover regardless of herbicide type, and the damage from herbicide was limited $(<10)$. Selective cutting and mowing both resulted in reduced prostrate-shrub cover of $\sim 2 \%$.

Forb cover decreased across all treatments with declines ranging from $-2.2 \%$ to $-12.0 \%$; there were few differences between treatments (Figure 2). Visual herbicide damage was more evident in imazapyr than triclopyr plots regardless of application type. Both broadcast spray treatments reduced cover by $\sim 10 \%$. Cut-stump plots 
also caused a similar decrease in cover of $-8.0 \%$ $( \pm 2.2 \mathrm{SE}, \mathrm{n}=12)$ and $-5.3 \%( \pm 3.4 \mathrm{SE}, \mathrm{n}=12)$. Forb cover decreased slightly in both point-injection treatments with means of $-2.2 \% \pm 2.1 \mathrm{SE}, \mathrm{n}=12$ (triclopyr) and $-3.5 \% \pm 1.7 \mathrm{SE}, \mathrm{n}=12$ (imazapyr). Selective cutting caused a reduction in cover similar to all other treatments, and a minor decrease in forb cover was also measured in mowing plots.

Triclopyr's mode-of-action targets dicots, and thus graminoid cover was not affected by triclopyr treatments. Imazapyr reduced graminoid cover with broadcast spray and cut-stump applications, resulting in similar changes of $-11.0 \%( \pm 1.2 \mathrm{SE}, \mathrm{n}$ $=12)$ and $-10.2 \%( \pm 3.7 \mathrm{SE}, \mathrm{n}=12)$ and point injection plots showing a $5.7 \%( \pm 2.3 \mathrm{SE}, \mathrm{n}=12)$ decrease in cover. Selective cutting resulted in $<2.0 \%$ reduction in cover, and mowing decreased graminoid cover by $4.9 \%( \pm 2.1 \mathrm{SE}, \mathrm{n}=2)$. Damage assessments were consistent with the cover data: only imazapyr treatments caused substantial damage. Imazapyr broadcast spray was the most damaging (59 \pm 8.2SE, $\mathrm{n}=12)$, followed by cut stump $(9 \pm 5.4 \mathrm{SE}$, $\mathrm{n}=11)$ and point injection $(8 \pm 2.9$ SE, $\mathrm{n}=11)$.

\section{Vascular Plant Community Change}

Differences in plant communities were observed among sites, with the DAW site being the most distinct. While HJ1, HJ2, and CAR were generally characterized by a grassy understory of purple reedgrass (Calamagrostis purpurascens), Pumpelly's brome (Bromus pumpellianus), and glaucous bluegrass, DAW was characterized by a moist ericaceous community dominated by bog bilberry (Vaccinium uliginosum) and Labrador tea (Rhododendron groenlandicum). Differences in plant communities between sites was confirmed by PERMANOVA (Site: $\mathrm{F}_{3}=14.78, P<0.01$ ).

Treatments altered species composition and abundance (PERMANOVA, Treatment: $\mathrm{F}_{7}=$ $2.11, P<0.01)$ with similar effects across sites (Site:Treatment: $\mathrm{F}_{21}=1.07, P=0.21$ ), but individual species responses to treatments were generally not consistent. Exceptions included two abundant erect shrubs at the DAW site, where bog bilberry and Labrador tea both increased in cover substantially in the triclopyr point-injection plots. In addition, the dominant bunchgrass at the CAR, HJ1, and HJ2 sites, purple reedgrass, decreased in cover in all plots treated with ima- zapyr. Changes in cover of dominant species between 2014 and 2015 are summarized in Table 2.

Species richness and evenness were homogeneous among plots within each site prior to treatment (richness: $P=0.79$, evenness: $P=0.69$ ) and different among sites $(P<0.01)$. One year after treatment, species richness and evenness remained different between sites, but only species richness was affected by treatment (Figure 4). Mean species richness was lowest in imazapyr broadcast spray plots, and highest in imazapyr point-injection plots. There was no interaction between site and treatment.

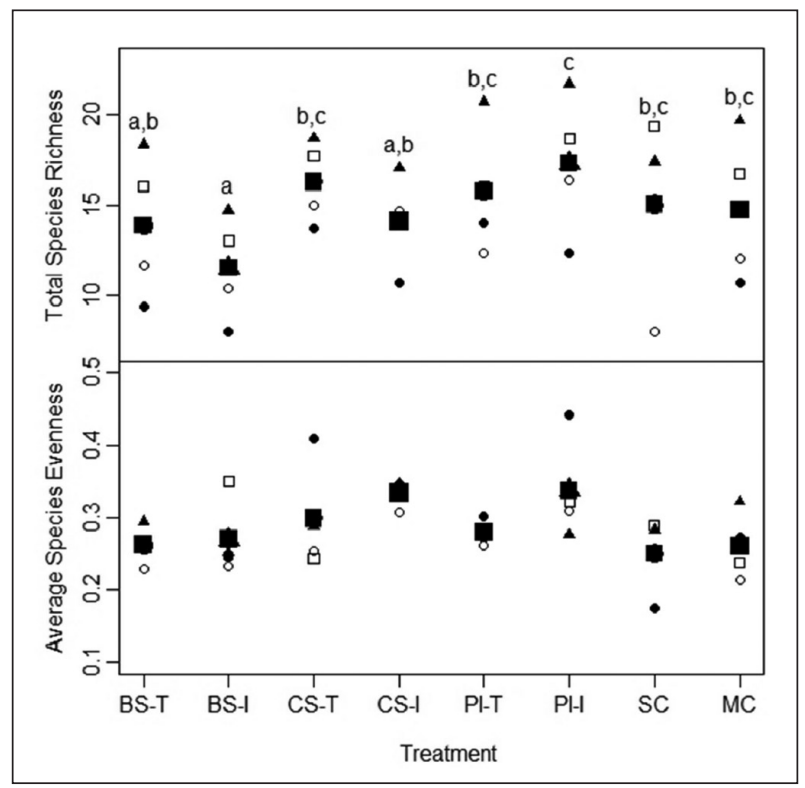

Figure 4. Average and by-site species richness and evenness one year after eight ROW management treatments in Yukon ( $\square=$ Average, $\bullet=$ CAR, $\Delta=$ DAW, $O=$ HJ1, $\square=$ HJ2). Richness and evenness differed by site (Richness: $F_{3,62}=$ 23.1, $P<0.01$; Evenness: $F_{3,62}=17.29, P<0.01$ ); however, treatment only influenced species richness (Richness: $F_{7,62}$ $=3.44, P<0.01$; Evenness: $F_{7,62}=1.82, P=0.10$ ). Interactions between site and treatment were not significant for either (Richness: $F_{21,62}=1.04, P=0.43$; Evenness: $F_{21,62}=0.98, P$ $=0.50$ ). Different letters indicate statistically significant differences between least square means. Treatment codes are described in Table 4.

\section{DISCUSSION}

Treatments successfully induced changes in vascular plant communities within one year. Control of target species one year following treatment ranged $66 \%-94 \%$ in chemically-treated plots, while mechanical removal of targets with or without grass seeding provided less than 55\% control. Distur- 
bance of non-target species due to treatments generally caused a neutral or minor negative change in erect shrub, prostrate shrub, forb, and graminoid cover. Both target and non-target vegetation displayed signs of imazapyr damage one year after application. Leaf chlorosis, stunted growth, and tissue deformity of many species occurred after broadcast spraying, as well as after selective cutstump and point-injection treatments. Herbicide damage to non-target species that were not directly treated suggests imazapyr transferred from target species by an unknown belowground mechanism. Imazapyr is known to have a lower sorption potential, higher mobility potential, and to persist longer than triclopyr (Tu et al. 2001). Detectable residues of imazapyr have been observed at 454 and 730 days after application in Alaska, U.S. and in Sweden (Torstenssen and Stark 1982; Newton et al. 2008). Other treatment effects were life-form- or speciesspecific, which is encouraging; treatments were designed to impact life-forms differently based on species' height and physiology (e.g., monocot versus dicot) to induce different recovery trajectories. Additional species-specific information and photographs will be available online (Isbister 2016).

\section{Control of Target Species}

Control of target species by chemical treatments one year following application was highly successful. The current study demonstrates that triclopyr and imazapyr applications on northern ROWs are just as effective at short-term control of woody species as they are in southern jurisdictions (Bramble et al. 1991; Luken et al. 1991; Mercier et al. 2001; Yahner and Hutnik 2004). Chemical treatments reduced target species cover by as much as $94 \%$ of their original abundance compared to less than $50 \%$ reduction by mowing. The high level of control also confirms the findings of Seefeldt et al. (2013), who demonstrated that 2,4-D and triclopyr can be effective for woody species control in northern conditions. Recovery of target species in chemical treatment plots to mowing control levels is unlikely to occur rapidly as damage assessments of treated stems indicated nearly lethal damage.

Poplar stems were significantly less visually damaged than birch and aspen, although this was not evident in the percent control analysis.
Differences in herbicide sensitivity between aspen and poplar have also been reported elsewhere; however, which species is more susceptible depends on the herbicide's active ingredient (Sharma and Vanden Born 1970; Bowes and Spurr 1996). Whether less visual damage indicates poplar will recover faster than other target species will require future measuring.

\section{Response of Non-Target Vegetation}

A small decrease in total non-target vascular plant cover after one year was observed across all eight treatments. This was not unexpected as decreases in shrub and herbaceous cover are commonly reported one year after both mechanical and chemical site preparation techniques in boreal clear cuts (Sullivan et al. 1996; Man et al. 2010). As treatments were applied by hand, trampling damage would also have occurred in all plots. The recovery of forbs and substantial increase in grass cover two years after triclopyr broadcast spray and cut-stump applications has been demonstrated in both boreal forests and rangelands (Bell and Newmaster 2002; Seefeldt et al. 2013). It is likely that herbaceous species abundance on Yukon ROWs will increase by the second year after triclopyr treatments. Recovery time for shrubs after triclopyr applications is less consistent, ranging from two to five years (Bell and Newmaster 2002; Seefeldt et al. 2013). In contrast, imazapyr treatments continued to cause visible herbicide damage to non-target vegetation after one year and may inhibit species recovery for a prolonged period.

Imazapyr broadcast spray, though most effective at controlling target species, also caused greater visual damage and cover reduction to non-target vegetation than other treatments. Prostrate shrubs were the exception, and the most common species, kinnikinnick, appeared to tolerate imazapyr well. In addition to damage after spraying, imazapyr damage to non-target species that were not directly treated also occurred in cut-stump and pointinjection plots. Chlorosis, deformity, and stunting of forbs was common after both treatments, but severity was highly species-specific. The variability in sensitivity confirms plant species exhibit a large range of tolerances to imazapyr (Bovey and Senseman 1998; Douglass et al. 2016). Graminoids were not as visually damaged as forbs; however, graminoid cover declined significantly after cut-stump, 
and to a lesser degree, point-injection treatments. Erect shrubs had visible imazapyr damage in pointinjection plots, and this was also reflected in a reduction of cover. Species richness was not reduced after imazapyr cut-stump or point-injection treatments but was lower in broadcast spray plots, indicating non-target plants were exposed to smaller imazapyr concentrations from selective treatments than from broadcast spray. These imazapyr concentrations in cut-stump and point-injection plots were not toxic enough to prevent non-target species germination, but had sufficient potency to cause visible tissue deformation and damage.

The substantial damage to, and in some cases cover reduction of, non-target species with selective application of imazapyr suggests some form of belowground transfer of imazapyr from treated stems. Non-target impacts from selective imazapyr treatments have been noted previously (Kochenderfer et al. 2001; DiTomaso and Kyser 2007; Lewis and McCarthy 2008). Potential transfer mechanisms include indirect soil contamination by root exudation and/or leaf senescence or direct transmission through mycorrhizal fungi or root grafts (Lewis and McCarthy 2008). Root exudation of imazapyr has been demonstrated in both woody and herbaceous plants, and once excreted, imazapyr is relatively mobile in soil and can be reabsorbed by other plant roots (Kanampiu et al. 2002; Silva et al. 2004). Imazapyr translocation studies also indicate that much of foliar applied imazapyr remains in the treated leaves (Tucker et al. 1994; Bernards et al. 2009), and contamination of soil by herbicide residues from decomposing plant material has been observed (Newton et al. 1990; Ranft et al. 2010). Nutrient transfer between plants through mycorrhizal networks is well-documented (e.g., Simard and Durall 2004), as is the transfer of allelochemicals (Barto et al. 2011; Achatz et al. 2014). Imazamox, an imidazolinone herbicide closely related to imazapyr, was used an experimental surrogate for an allelochemical and was transferred between a treated and untreated plant exclusively through mycorrhizal connections (Barto et al. 2011). Mycorrhizae are abundant in boreal soils (Lindahl et al. 2007), and these networks between vascular plants likely exist on Yukon ROWs. There is little known about herbicide transfer through root grafts; however, the transfer of 2,4,5-T in sweetgum (Liquidambar styraciflua) has been reported (Fenton 1965). Regardless of the transfer mechanism, herbicide damage assessments clearly indicated continual imazapyr activity 365 days after both selective and non-selective applications.

Other than imazapyr causing more visible damage to non-target species, responses to treatments were life-form- or species-specific. The results of the current study are encouraging, as treatments were designed to selectively disturb species based on their morphological and physiological characteristics. For example, cut-stump herbicide applications targeted individual plants of $20 \mathrm{~cm}$ height or greater with the intent of not disturbing low-growing vegetation, while broadcast spray applications favor species with intrinsic tolerance of the herbicide active ingredients. Cut-stump and broadcast spray treatments would therefore promote different species and thus encourage the development of different plant communities. The two cover types identified as having the most potential for inhibiting target species establishment on Yukon ROWs were shrub or grass dominated communities. Neither the use of a broadleaf selective herbicide (triclopyr) nor the additional seeding of a native grass seed mix increased graminoid cover after one year, although new seedlings were noted at all sites. The point-injection and selective-cutting methods intended to promote erect-shrub cover were only partially successful after one year, as selective cutting and point injection of triclopyr resulted in a neutral or positive cover change. The most substantial increase in erect-shrub cover was at the DAW site where bog bilberry cover increased by $>15 \%$ in triclopyr point-injection plots. Cover of bog bilberry did not increase when only aboveground target species biomass was cut and removed in selective cutting plots. Triclopyr point-injection treatments provided substantial control of target species and a release from competition could explain the increase in bog bilberry cover. Although these results are very preliminary, they are the first indicators of suitable shrub species for moist, acidic sites.

Understanding species-treatment interactions is critical to selecting effective management methods that promote desirable cover types. The dramatic decrease in prostrate-shrub cover one year after triclopyr broadcast spray applications is a good example of why knowledge of specific herbicide-species impacts are important. Kinnikinnick accounted for 
$68 \%$ of the total prostrate-shrub cover across sites prior to treatment, and damage assessments confirmed the species was highly sensitive to foliarapplied triclopyr. Triclopyr broadcast spray is thus a less-desirable choice for a site like HJ1, where kinnikinnick comprises a large percentage of the understory cover and its low growth form is compatible with ROW management objectives. Further monitoring measurements are required to confirm additional relationships between treatments and species' abundances as plant communities continue to respond after vegetation management disturbances.

\section{Vascular Plant Community Change}

Herbicide applications to boreal ecosystems can cause both short- and long-term effects on plant communities (Strong and Sidhu 2005). Significant changes to the vascular plant communities in response to treatments occurred at the sites after one year, as species responded to the disturbances differently. Clear directional changes of plant communities as a whole, however, were not yet apparent. Only two treatments had an effect on species richness, with lower richness in imazapyr broadcast spray plots and higher in point injection with imazapyr. All other treatments' species richness values were similar and evenness was consistent between all treatments. Long-term studies of glyphosate and hexazinone site preparation treatments show few impacts on boreal species richness and evenness (Sullivan and Sullivan 2003; Strong and Sidhu 2005), which suggests that such changes should not be expected. When a change in richness is reported after boreal site preparation, it is often an increase associated with invasion of weedy species (Bell and Newmaster 2002); weed invasion was not observed at any site in the current study.

Evidence of early community changes indicates the initial floristic compositions of treatment plots were altered and the development of new, distinct communities can be expected over time (Egler 1954; Niering 1987; Strong and Sidhu 2005). In the boreal forest, the most important changes in species composition and abundance occurs in the year following disturbance (de Grandepre and Bergeron 1997) and this likely applies to Yukon ROWs. The ability to characterize future communities and their capacity to resist the re-growth or invasion of target species, however, is limited by the length of the study. Yukon
ROWs are currently mowed every 8-10 years, and at least one cycle is needed to fully evaluate community development. How species-treatment relationships are influenced by inter-annual weather variations were not explored, as treatments were only applied in one season. Vegetation responses to treatments were similar among sites, suggesting weather did not significantly affect plant responses, but this relationship was not examined directly. Future studies would benefit from employing larger treatment areas and use of operational equipment (e.g., use of mowers and wet blading equipment versus hand cutting) to better determine large-scale operational conditions. The long-term comparative costs of mowing versus chemical treatment need to be defined, and will depend, in part, on the number of chemical treatment cycles required to achieve a low-maintenance competitive vegetative cover. As monitoring continues and knowledge of the ecosystem dynamics increases over time, vegetation management strategies can be adapted and improved. This continuous evaluation and adaptation of management techniques is fundamental to integrated vegetation management (Nowak and Ballard 2005) and this study provides the foundation for the development of an IVM program for Yukon ROWs.

\section{CONCLUSION}

Understanding vegetation dynamics and how those dynamics are influenced by management methods are critical components of IVM for power line ROWs. Researchers evaluated eight management treatments on their control of target species and impacts on non-target plant species and communities. Changes in vascular plant composition and abundance were successfully induced one year after treatments. Developments into new, distinct plant communities were not clear due to the short time frame of the study; however, strong speciesspecific responses to treatments were detected. The current study demonstrates that even in cool northern conditions, effective short-term control of target species can be achieved with herbicide applications of triclopyr and imazapyr. Triclopyr treatments were much more successful than imazapyr treatments at minimizing damage and cover reduction of non-target vegetation. The prostrate shrub, kinnikinnick, was an exception, and was significantly more susceptible to broadcast spraying 
of triclopyr than imazapyr. Selective application of triclopyr (i.e., cut stump and point injection) was effective at controlling target species one year following application and also reduced impact on nontarget species compared with broadcast spraying.

Both selective and non-selective imazapyr treatments caused deformity and chlorosis of non-target vegetation one year after application, though severity was species specific. This strongly suggests imazapyr can remain active in the soil for more than one season in northern conditions; longer than the typical 25-142 day half-life (Senseman 2007). Damage to species that were not directly treated also indicates that imazapyr can also transfer through an unknown belowground mechanism. The residual activity and transfer mechanism of imazapyr raises concerns about its use on Yukon ROWs. The range of sensitivities of northern boreal plants to imazapyr and triclopyr applications, as well as the potential for their persistence in soil, also highlights the need for more focused toxicity research in the north.

Acknowledgements. We thank the three anonymous reviewers who provided insightful and constructive comments that greatly improved earlier versions of this manuscript. We wish to thank both partners on the project-Yukon Energy Corporation and Environmental Dynamics Inc. for their financial support and in-kind contributions. We are also grateful to Aaron Roberge, Alexandra de Jong Westman, Alexandre Mischler, Amy Jimmo, Annie-Claude Letendre, David Silas, Denise Gordon, Isobel Ness, and Patrick Soprovich for their assistance in the field. We thank the Yukon Wildland Fire Management Program for providing weather data for each site. Additional funding was provided through NSERC ARD grants, the Yukon College Research Fund, and an Association of Canadian Universities for Northern Studies scholarship awarded to K. Isbister.

\section{LITERATURE CITED}

Achatz, M., E.K. Morris, F. Müller, M. Hilker, and M.C. Rillig. 2014. Soil hypha-mediated movement of allelochemicals: Arbuscular mycorrhizae extend the bioactive zone of juglone. Functional Ecology 28:1020-1029.

Amiro, B.D., and G.M. Courtin. 1981. Patterns of vegetation in the vicinity on an industrially disturbed ecosystem, Sudbury, Ontario. Canadian Journal of Botany 59:1623-1639.

Anderson, M.J. 2001. A new method for non-parametric multivariate analysis of variance. Austral Ecology 26:32-46.

Ballandier, P., C. Collet, J.H. Miller, P.E. Reynolds, and S.M. Zedaker. 2006. Designing forest vegetation management strategies based on the mechanisms and dynamics of crop tree competition by neighbouring vegetation. Forestry 79:3-27.

Ballard, B.D., H.L. Luczak, and C.A. Nowak. 2011. Northeastern shrub and short tree identification: A guide for right-of-way vegetation management. Research Foundation of the State University of New York, Liverpool, New York, U.S. 138 pp.
Barto, E.K., M. Hilker, F. Müller, B.K. Mohney, J.D. Weidenhamer, and M.C. Rillig. 2011. The fungal fast lane: Common mycorrhizal networks extend bioactive zones of allelochemicals in soils. PLOS One 6(11):e27195 <doi:10.1371/journal.pone.0027195>

Bell, W.F., and S.G. Newmaster. 2002. The effects of silvicultural disturbances on the diversity of seed-producing plants in the boreal mixedwood forest Canadian Journal of Forest Research 32:1180-1191.

Bernards, M., D. Penner, and J. Michael. 2009. Imazapyr absorption and translocation in northern red oak and red maple as affected by herbicide formulation and the adjuvant methylated seed oil. Journal of ASTM International 6:1-10.

Bovey, R.W., and S.A. Senseman. 1998. Response of food and forage crops to soil-applied imazapyr. Weed Science 46:614-617.

Bowes, G.G., and D.T. Spurr. 1996. Control of aspen poplar, balsam poplar, prickly rose, and western snowberry with metsulfuronmethyl and 2,4-D. Canadian Journal of Plant Science 76:885-889.

Bramble, W.C., W.R. Byrnes, R.J. Hutnik, and S.A. Liscinsky. 1991. Prediction of cover type on rights-of-way after maintenance treatments. Journal of Arboriculture 17:38-43.

Brown, D. 1995. The impact of species introduced to control tree invasion on the vegetation of an electrical utility right-of-way. Canadian Journal of Botany 73:1217-1228.

Carleton, T.J., and P. MacLellan. 1994. Woody vegetation responses to fire versus clear-cutting logging: A comparative survey in the central Canadian boreal forest. Ecoscience 1:141-152.

de Grandpre, L., and Y. Bergeron. 1997. Diversity and stability of understory communities following disturbance in the southern boreal forest. Journal of Ecology 85:777-784.

DiTomaso, T.M., and G.B. Kyser. 2007. Control of Ailanthus altissima using stem herbicide application techniques. Arboriculture \& Urban Forestry 33:55-63.

Douglass, C.H., Nissen S.J., Meiman P.J., and A.R. Kniss. 2016. Impacts of imazapyr and triclopyr soil residues on the growth of several restoration species. Rangeland Ecology and Management 69:199-205.

Dreyer, G., and W. Niering. 1986. Evaluation of two herbicide techniques on electric transmission rights-of-way: Development of relatively stable shrublands. Environmental Management 10:113-118.

Egler, F.E. 1954. Vegetation science concepts I. Initial floristic composition. A factor in old-field vegetation development. Vegetatio 4:412-417.

Environmental Dynamics Inc. (EDI). 2009. A review of several Yukon revegetation projects and techniques. MPERG Report No. 2009-3. Yukon Territory, Canada. 118 pp.

Environmental Dynamics Inc. (EDI). 2013. Chemical Vegetation Control and Monitoring. Report No. 12-Y-0265. Prepared for Yukon Energy Corporation, Whitehorse, Yukon Territory, Canada. $81 \mathrm{pp}$.

Environment Canada. N.d. 1981-2010 climate normals and averages. Accessed 04 April 2016. <http://climate.weather.gc.ca/climate_normals/index_e.html>

Fenton, R. 1965. Root grafts and translocation of 2,4,5-T in young sweetgum stands. Journal of Forestry 63:16-18.

Frey, B.R., V.J. Lieffers, A.D. Munson, and P.V. Blenis. 2003. The influence of partial harvesting and forest floor disturbance on nutrient availability and understory vegetation in boreal mixedwoods. Canadian Journal of Forest Research 33:1180-1188. 
Ilisson, T., and H.Y.H. Chen. 2009. Response of six boreal tree species to stand replacing fire and clearcutting. Ecosystems $12: 820-829$.

Isbister, K. 2016. Vegetation management strategies for northern rights-of-way: Effects on boreal plant communities and the toxicological response of select native species to triclopyr and imazapyr [M.Sc. Thesis]. University of Saskatchewan, Saskatoon, Saskatchewan, Canada.

Kanampiu, F.K., J.K. Ransom, D. Friesen, and J. Gressel. 2002. Imazapyr and pyrithiobac movement in soil and from maize seed coats to control Striga in legume intercropping. Crop Protection 21:611-619.

Kochenderfer, J., S. Zedaker, J. Johnson, D. Smith, and G. Miller. 2001. Herbicide hardwood crop tree release in central West Virginia. Northern Journal of Applied Forestry 18:46-64.

Kuznetsova, A., P.B. Brockhoff, and R.H.B. Christensen. 2014. lmerTest: Tests in linear mixed effects models. $\mathrm{R}$ package version 2.0-20.<http://CRAN.R-project.org/package=lmerTest $>$

Landhäusser, S.M., and V.J. Lieffers. 1998. Growth of Populus tremuloides in association with Calamagrostis canadensis. Canadian Journal of Forest Research 28:396-401.

Landhäusser, S.M., T.L. Mulak, and V.J. Lieffers. 2007. The effect of roots and litter of Calamagrostis canadensis on root sucker regeneration of Populus tremuloides. Forestry 80:481-488.

Lewis, K., and B. McCarthy. 2008. Nontarget tree mortality after Tree-of-Heaven (Ailanthus altissima) injection with imazapyr. Northern Journal of Applied Forestry 25:66-72.

Lindahl, B., K. Ihrmark, J. Boberg, S. Trumbore, P. Högberg, J. Stenlid, and R. Finlay. 2007. Spatial separation of litter decomposition and mycorrhizal nitrogen uptake in a boreal forest. The New Phytologist 173:611-620.

Luken, J.O., A.C. Hinton, and D.G. Baker. 1991. Assessment of frequent cutting as a plant-community management technique in power-line corridors. Environmental Management 15:381-388.

Man, R., J.A. Rice, and G.B. MacDonald. 2010. Five-year light, vegetation, and regeneration dynamics of boreal mixedwoods following silviculture treatments to establish productive aspenspruce mixtures in northeastern Ontario. Canadian Journal of Forest Research 40:1529-1541.

McLoughlin, K.T. 2014. Integrated Vegetation Management: From its roots in IPM to the present. pp. 227-270. In: G.J. Doucet (Ed.). Proceedings of the 10th International Symposium: Environmental Concerns in Rights-of-Way Management. Utility Arborist Association, Champaign, Illinois, U.S.

Meilleur, A., H. Veronneau, and A. Bouchard. 1994. Shrub communities as inhibitors of plant succession in southern Quebec. Environmental Management 18:907-921.

Mercier, C., J. Brison, and A. Bouchard. 2001. Demographic analysis of tree colonization in a 20-year-old right-of-way. Environmental Management 28:777-787.

Newton, M., E.C. Cole, and I.J. Tinsley. 2008. Dissipation of four forest-use herbicides at high latitudes. Environmental Science and Pollution Research 15:573-583.

Newton, M., F. Roberts, A. Allen, B. Kelpsas, D. White, and P. Boyd. 1990. Deposition and dissipation of three herbicides in foliage, litter, and soil brushfields of Southwest Oregon. Journal of Agricultural and Food Chemistry 38:574-583.

Niering, W.A. 1987. Vegetation dynamics (succession and climax) in relation to plant community management. Conservation Biology 1:287-295.
Niering, W.A., and R.H. Goodwin. 1974. Creation of relatively stable shrublands with herbicides: Arresting "succession" on rights-of-way and pastureland. Ecology 55:784-795.

Nowak, C.A., and B.D. Ballard. 2005. A framework for applying integrated vegetation management on rights-of-way. Journal of Arboriculture 31:28-37.

Oksanen, J., F.G. Blanchet, R. Kindt, P. Legendre, P.R. Minchin, R.B. O'Hara, G.L. Simpson, et al. 2015. Vegan: Community ecology package. R package version 2.3-1. <http://CRAN.R-project.org/ package $=$ vegan $>$

Pickett, S.T.A., M.L. Cadenasso, and S.J. Meiners. 2009. Ever since Clements: From succession to vegetation dynamics and understanding to intervention. Applied Vegetation Science 12:9-21.

R Core Team. 2015. R: A language and environment for statistical computing. R Foundation for Statistical Computing, Vienna, Austria. <www.R-project.org>

Ranft, R.D., S.S. Seefeldt, M. Zhang, and D.L. Barnes. 2010. Development of a soil bioassay for triclopyr residues and comparison with a laboratory extraction. Weed Technology 24:538-543.

Rosenberg, D.B., and S.M. Freedman. 1984. Applying a model of ecological succession to conservation and land-use management. International Journal of Environmental Studies 23:11-18.

Royo, A.A., and W.P. Carson. 2006. On the formation of dense understory layers in forests worldwide: Consequences and implications for forest dynamics, biodiversity, and succession. Canadian Journal of Forest Research 36:1345-1362.

Seefeldt, S.S., P.N. Kaspari, and J.S. Conn. 2013. Shrub control in conservation reserve program lands in interior Alaska. Weed Technology 27:184-189.

Senseman, S.A. 2007. Herbicide Handbook, ninth edition. Weed Science Society of America, Lawrence, Kansas, U.S. 458 pp.

Sharma, M.P., and W.H. Vanden Born. 1970. Foliar penetration of picloram and 2,4-D in aspen and balsam poplar. Weed Science 18:57-63.

Silva, C.M.M., L. Ferreira, F. Ferreira, and G. Miranda. 2004. Root exudation of imazapyr by eucalypt, cultivated in soil. Planta Daninha 22:109-116.

Simard, S., and D. Durall. 2004. Mycorrhizal networks: A review of their extent, function, and importance. Canadian Journal of Botany 82:1140-1165.

Smith, B., and J.B. Wilson. 1996. A consumer's guide to evenness indices. Oikos 76:70-82.

Smith, C.A.S., J.C. Meikle, and C.F. Roots (Eds.). 2004. Ecoregions of the Yukon Territory: Biophysical properties of Yukon landscapes. Agriculture and Agri-Food Canada, PARC Technical Bulletin No. 04-01, Summerland, British Colombia, Canada. 313 pp.

Strong, W.L., and S.S. Sidhu. 2005. Prolonged herbicide-induced vegetation changes in a regenerating boreal aspen clearcut. Journal of Environmental Management 77:194-204.

Sullivan, T.P., and D.S. Sullivan. 2003. Vegetation management and ecosystem disturbance: Impact of glyphosate herbicide on plant and animal diversity in terrestrial systems. Environmental Reviews 11:37-59.

Sullivan, T.P., R.A. Lautenschlager, and R.G. Wagner. 1996. Influence of glyphosate on vegetation dynamics in different successional stages of sub-boreal spruce forest. Weed Technology 10:439-446. 
Torstenssen, I., and J. Stark. 1982. Persistence of Triclopyr in Forest Soils. pp. 393-399. In: 23rd Swedish Weed Conference. Uppsala Sweden Department of Plant Horticulture, Uppsala, Sweden.

Tu, M., C. Hurd, R. Robinson, and J.M. Randall. 2001. Weed control methods handbook: Tools and techniques for use in natural area. The Nature Conservancy. Version: April 2001. <http://tncweeds.ucdavis.edu>

Tucker, T., K. Langeland, and F. Corbin. 1994. Absorption and translocation of C14-imazapy and C14-glyphosate in alligatorweed Alternanthera philoxeroides. Weed Technology:32-36.

White M.P., Smith S., Kroetsch D., K. and McKenna. 1992. Soil landscapes of Canada: Yukon Territory. Agriculture and AgriFood Canada. Accessed 21 February 2015. <http://sis.agr.gc.ca/ cansis/publications/maps/slc/1m/v1/slc_1m_v1_yukon.jpg>

Yahner, R.H., and R.J. Hutnik. 2004. Integrated vegetation management on an electric transmission right-of-way in Pennsylvania, U.S. Journal of Arboriculture 30:295-300.

\author{
Krystal M. Isbister \\ Department of Plant Sciences \\ University of Saskatchewan \\ 51 Campus Drive \\ Saskatoon, Saskatchewan, Canada \\ S7N 5 A8
}

Eric G. Lamb,

Department of Plant Sciences

University of Saskatchewan

51 Campus Drive

Saskatoon, Saskatchewan, Canada

S7N $5 A 8$

\author{
Katherine J. Stewart (corresponding author) \\ Department of Plant Sciences \\ University of Saskatchewan \\ 51 Campus Drive \\ Saskatoon, Saskatchewan, Canada \\ S7N $5 A 8$ \\ Katherine.Stewart@usask.ca
}

and

Yukon Research Centre

Yukon College

500 College Drive

Whitehorse, Yukon, Canada

Y1A $5 K 4$
Résumé. Les programmes de gestion intégrée de la végétation ont réussi à réduire la fréquence et l'intensité de l'entretien des emprises de lignes électriques en favorisant la croissance d'une communauté végétale basse et résistante à l'envahissement par les arbres. Pour valider si ces principes peuvent être appliqués aux écosystèmes davantage nordiques, des chercheurs ont testé huit traitements sur quatre sites au Yukon, Canada. Deux herbicides, l'Imazapyr et le Triclopyr, ont été appliqués selon trois méthodes, ainsi qu'un traitement d'ensemencement de plantes herbacées indigènes et une régie de fauchage des végétaux en place. La couverture végétale a été évaluée avant traitement et un an plus tard en parallèle avec une appréciation des dommages causés par les herbicides. Dans l'ensemble, tous les traitements ont provoqué des changements significatifs dans les communautés de plantes vasculaires après un an. Le contrôle à court terme des espèces ligneuses ciblées s'est avéré plus efficace dans les parcelles traitées chimiquement (66\% à $94 \%)$ que dans les parcelles traitées mécaniquement (moins de $55 \%$ ). Tous les traitements ont entraîné une réduction mineure de la couverture végétale non ciblée. Dans les parcelles ensemencées, les semis ont émergé, mais la couverture totale des espèces non ciblées a été réduite en raison de la préparation du sol pour son ensemencement. La pulvérisation à la volée du Triclopyr a réduit la couverture de végétation non-ciblée de moins de $10 \%$, mais un arbuste commun, l'arctostaphyle raisin-d'ours (Arctostaphylos uva-ursi), a été extrêmement affecté. L'application sélective de Triclopyr a contrôlé de façon efficace les espèces ciblées avec un impact minime chez les plantes non-ciblées. L'Imazapyr a invariablement causé plus d'impacts chez les plantes non-ciblées que le Triclopyr. Les applications sélectives et non sélectives d'Imazapyr ont généré des chloroses, un retard de croissance et une déformation des arbustes et des plantes herbacées un an après le traitement. Cela suggère que l'Imazapyr peut demeurer actif dans les sols nordiques pendant au moins 365 jours et qu'il peut même se déplacer et affecter des plantes non traitées. L'étendue des sensibilités constatées chez les espèces de plantes boréales à l'Imazapyr et au Triclopyr ainsi que leur persistance potentielle dans les sols nordiques témoignent bien de la nécessité de recherches approfondies sur la toxicité dans le Nord.

Zusammenfassung. Integrierte VegetationsmanagementProgramme haben die Frequenz und Intensität des Management von Starkstromleitungskorridoren erfolgreich reduziert, indem langsam wachsende Pflanzenpopulationen, die resistent gegenüber Bauminvasionen sind, eine Promotion erhielten. Um herauszufinden, ob sich diese Prinzipien auch auf nördliche Ökosysteme übertragen lassen, testeten Forscher acht verschiedene Behandlungen an vier Standorten in Yukon, Canada. Zwei Herbizide, Imazapyr und Triclopyr, wurden mit drei verschieden Methoden appliziert, genauso wie die Aussaat von nativen Gräsern und eine Kontrolle, die nur gemäht wurde. Die Vegetationsbedeckung wurde vor der Behandlung und ein Jahr später mit den Auswirkungen der Herbizidbehandlung aufgezeichnet. Im Ganzen erzeugten die Behandlungen innerhalb eines Jahres signifikante Veränderungen bei den vaskulären Pflanzengesellschaften. Eine kurzzeitige Kontrolle der holzigen Zielarten war bei chemisch behandelten Standorten gröBer (66\%-94\%) als bei den mechanischen Methoden ( $<55 \%)$. Alle Behandlungen verursachten eine untergeordnete Kontrolle bei den Pflanzen außerhalb der Zielgruppe. An den Standorten mit Aussaat kamen zwar unerwünschte Keimlinge vor, wurden aber durch die Saatbeetbereitung reduziert. Triclopyr als Breitbandspray reduzierte die Vegetationsbedeckung außerhalb der Zielgruppe um $<10 \%$, aber der häufige Strauch Arctostaphylos uva-ursi war sehr betroffen. Selektive Applikationen von Triclopyr kontrollierten effektiv die Zielgruppe mit geringen Auswirkungen auf die Pflanzen außerhalb der Zielgruppe. Imazapyr verursachte deutlich mehr Auswirkugnen auf die Pflanzen außerhalb der Zielgruppe. Beide selektive und nicht-selektive Imazapyr-Applikationen verursachten Chlorose, 
Zwergenwuchs und Deformierung von Sträuchern und Büschen bis zu einem Jahr nach der Behandlung. Das bedeutet, dass Imazapyr in den nördlichen Böden mindestens 365 Tage aktiv bleiben und auch zu unbehandelten Pflanzen übertragen werden. Die Spannbreite der Empfindlichenkeiten von borealen Pflanzenarten auf Triclopyr und Imazapyr und die potentielle Persistenz in nördlichen Böden hebt die Notwendigkeit einer fokussierten Toxizität-Studie im Norden hervor.

Resumen. Los programas integrados de manejo de la vegetación han reducido con éxito la frecuencia y la intensidad de la gestión del derecho de vía de la línea eléctrica mediante la promoción de comunidades de plantas de bajo crecimiento resistentes a la invasión de árboles. Para examinar si estos principios son transferibles a los ecosistemas del norte, los investigadores probaron ocho tratamientos en cuatro sitios en Yukon, Canadá. Dos herbicidas, imazapir y triclopir, se aplicaron por tres métodos, así como un tratamiento de siembra de pasto nativo y un control de siega. La cobertura de la vegetación se registró antes del tratamiento y después de un año junto con las evaluaciones de daños por herbicidas.

En general, los tratamientos causaron cambios significativos en las comunidades de plantas vasculares después de un año. El control a corto plazo de las especies objetivo leñosas fue mayor en las parcelas tratadas químicamente $(66 \%-94 \%)$ que con los métodos mecánicos $(<55 \%)$. Todos los tratamientos causaron una reducción menor en la cobertura vegetal no objetivo. En las parcelas sembradas, surgieron las plántulas, pero la cobertura total de las especies no objetivo se redujo mediante la preparación del lecho de siembra. La aspersión de Triclopyr redujo la cobertura vegetal no objetivo en $<10 \%$, pero el arbusto común, kinnickinnick (Arctostaphylos uvaursi), se vio muy afectado.

La aplicación selectiva de triclopyr controla eficazmente las plantas objetivo con efectos mínimos sobre las especies no objetivo. Imazapyr causó constantemente más impactos a las plantas no objetivo que el triclopyr. Las aplicaciones de imazapir tanto selectivas como no selectivas produjeron clorosis, atrofia y deformidad de arbustos y herbáceos un año después del tratamiento. Esto sugiere que imazapyr puede permanecer activo en suelos del norte durante al menos 365 días, así como también transferirse a plantas no tratadas. El rango de sensibilidades de las especies de plantas boreales a imazapir y triclopir y la persistencia potencial en suelos del norte resalta la necesidad de una investigación de toxicidad enfocada en el Norte. 